九州大学学術情報リポジトリ

Kyushu University Institutional Repository

Application of the Direct Colony TLC for Identification of Phytopathogenic Bacteria (III). Distinction of the Pseudomonads in the rRNA-homology Group II (Burkholderia Spp.)

Matsuyama, Nobuaki

Laboratory of Plant Pathology, Faculty of Agriculture, Kyushu University

https://doi.org/10.5109/24105

出版情報：九州大学大学院農学研究院紀要. 40 (1/2)，pp. 189-196，1995-12. Kyushu University バージョン：

権利関係 : 


\title{
Application of the Direct Colony TLC for Identification of Phyto- pathogenic Bacteria (III). Distinction of the Pseudomonads in the rRNA-homology Group II (Burkholderia Spp.)
}

\author{
Nobuaki Matsuyama \\ Laboratory of Plant Pathology, Faculty of Agriculture, \\ Kyushu University, Fukuoka 812-81, Japan \\ (Received July 31, 1995)
}

\begin{abstract}
The comparison of chromatographic profiles of pseudomonads in the rRNAhomologygroup II (Burkholderia gen. nov.) was conducted by using the direct colony TLC method. The chromatograms of Pseudomonas cepacia, n? caryophylli, $P$. glumae, $P$. gladioli, $P$. plantari, $P$. andropogonis, $P$. solanacearum and $P$. rubrisubalbicans resembled roughly each other. However, the profiles of three spots which were designated as S1, S2 and S3 were distinct at species level. The chromatograms of $P$. andropogonis, $P$. solanacearum and $P$. rubrisubalbicans were characteristic. Especially, the profile of Prubrisubalbicans was quite unique in these pseudomonads. So far as the chromatograms for aminolipids concerned, some similarities were observed between $P$. andropogonis and $P$. solanacearum. However, $P$. andropogonis was distinguishable with the existence of single spot which is detectable at $\mathrm{Rf}$ 0.83 by spraying of the chromium-containing $55 \%$ sulfuric acid and heating at $110^{\circ} \mathrm{C}$. The usefulness of the direct colony TLC method for rapid identification of phytopathogenic bacteria at species level was repeatedly verified.
\end{abstract}

\section{INTRODUCTION}

The direct colony thin layer chromatography was invented in 1986 (Matsuyama et al., 1986) and firstly applied for rapid identification of phytopathogenic bacteria (Matsuyama, 1993a, Matsuyama et $a l ., 1993 \mathrm{~b}, \mathrm{c}, \mathrm{d}$, Matsuyama and Furuya, 1993e). The differentiation of the phytopathogenic bacteria at generic level was available among Clavibacter, Agrobacterium and others. Further, in genus Erwinia, the profiles of E. chqsanthemi and $E$. carotovora subsp. carotovora were clearly different. These differences at species level were also observed in genus Pseudomonas. These results indicated practical usefulness of this easy method for rapid identification of phytopathogenic bacteria. During these experiments, the existence of several groups which had similarities for chromatographic profiles in pseudomonads was found. These groups were Cepacia-type, Syringae-type and Solanacearum-type (Matsuyama and Furuya, 1993e).

Recent progress in rRNA-DNA hybridization analysis for bacterial taxonomy influenced largely on the taxonomy of pseudomonads (Palleroni et al., 1973, De Vos and De Ley, 1983, Young et al., 1992). A new genus Burkholderia and the transferring of some members of Pseudomonas to this genus were proposed, recently (Yabuuchi et al., 1992).

In this report, the similarities and diversities of chromatographic profiles among the species of pseudomonads which were proposed to be transferred to a new genus

This study was supported in part by the Grant-in-aid from the Ministry of Education, Science and Culture of Japan (No. 06454064). 
Burkholderia will be presented.

\section{Isolates tested}

\section{MATERIALS AND METHODS}

The isolates of Cepacia-type pseudomonads (Burkholderia gen. nov.) were tested in this experiment. To validate the results obtained, the type cultures from ATCC (American Type Culture Collection) were also used. The details of isolates were presented in Table 1.

Table 1. Isolates of pseudomonads used in this experiment.

\begin{tabular}{|c|c|c|}
\hline Pseudomonas spp. & Isolates & Source \\
\hline P. cepacia & $356-5$ & NIAS \\
\hline \multirow[t]{2}{*}{ " } & ATCC $25416^{\mathrm{T}}$ & ATCC \\
\hline & 243-4 & NIAS \\
\hline P. caryophylli & 1192 & \\
\hline " & 1406 & $"$ \\
\hline P.gladioli pv. gladioli & 1064 & \\
\hline " & 1065 & " \\
\hline " & $251-17$ & $"$ \\
\hline$P$ plantarii & $\mathrm{AZ} 8201^{\mathrm{T}}$ & " \\
\hline \multirow[t]{2}{*}{ ", } & MAFF 302484 & NIAES \\
\hline & MAFF 302387 & " \\
\hline \multirow[t]{2}{*}{ P. glumae } & 2 & KNAS \\
\hline & N7503 & $\mathrm{AKU}$ \\
\hline " & 8112 & NIAS \\
\hline P. andropogonis & MAFF 301006 & NIAES \\
\hline " & MAFF 301129 & \\
\hline P. solanacearum & C319SR & KTES \\
\hline " & 6211 & NIAS \\
\hline " & ATCC $11696^{\top}$ & ATCC \\
\hline P. rubrisubalbicans & MAFF 301626 & NIAES \\
\hline " & MAFF 301628 & " \\
\hline Comamonas acidovorans & ATCC $15668^{\top}$ & ATCC \\
\hline
\end{tabular}

NIAS : National Institute of Agricultural Sciences, Tokyo, Japan. Isolates from NIAS were stocked in duplicate at Kyushu University by Dr. S. Wakimoto after the consolidation of the Institutes of the Ministry of Agriculture, Forestry and Fisheries.

NIAES: National Institute of Agro-Environmental Sciences, Tsukuba, Japan.

ATCC : American Type Culture Collection.

KTES : Kagoshima Tobacco Experiment Station, Kagoshima, Japan.

AKU : Faculty of Agriculture, Kyushu University, Fukuoka, Japan.

KNAS : Kyushu National Agricultural Experiment Station, Kumamoto, Japan.

Type culture: Type culture was indicated at the shoulder of isolate number as a small $\mathrm{T}$. 


\section{Culture of bacteria and methods of the direct colony thin-layer chromatography}

Isolates were cultured on the slant of King's B medium at $30^{\circ} \mathrm{C}$ for 3 days unless otherwise stated. One loopful bacterial cells of each bacterial isolate was pasted directly on the origin of pre-coated silica gel TLC plate (Merck Co., Si $60,0.25 \mathrm{~mm}$ in thickness) and completely dried in the autodesiccator for ca.1 hour and/or by hair-drier. At first, the TLC plate was developed with chloroform-methanol(2:1, v/v) for $10 \mathrm{~min}$. After the drying, the bacterial cells pasted were scraped off and the plate was developed to the same direction with chloroform-methanol-water $(60: 25: 4, \mathrm{v} / \mathrm{v} / \mathrm{v})$ for $1.5 \mathrm{hr}$. The developments were carried out in the incubator at $25^{\circ} \mathrm{C}$. After the development, the TLC plate was dried well, sprayed with ninhydrin and kept at $100^{\circ} \mathrm{C}$ for the detection of aminolipids. Detection by spraying of chromium-containing sulfuric acid $\left(0.6 \% \mathrm{~K}_{2} \mathrm{Cr}_{2} \mathrm{O}_{7}\right.$ in $55 \% \mathrm{H}_{3} \mathrm{SO}_{4}$ ) and heating at $110^{\circ} \mathrm{C}$ was conducted, also, for visualizing the benchmark spots of some pseudomonads. A frequent renewal of the TLC solvents in the glass vessels was carried out for a well reproducibility. The chromatograms were recorded by a photocopy. Other techniques have been presented in the former reports (Matsuyama et al., 1993b, c, d, Matsuyama \& Furuya, 1993e).

\section{RESULTS AND DISCUSSION}

The chromatographic profiles of the species in rRNA homology group II (Pseudomonas cepacia, P. caryophylli, P. gladioli pv. gladioli, P. glumae, P. plantarii, $P$. rubrisubalbicans, $P$. andropogonis and $P$. solanacearum) were compared to verify the practical usefulness of this convenient measure, the direct colony TLC, for the rapid identification of phytopathogenic bacteria at species level. In this rRNA homology group II in pseudomonads, the chromatographic differences at species level were obviously observed. Especially, the benchmark spots S1, S2 and S3 (Fig. 1) under the common spot ( Rf 0.62) represented well the characteristics of each species. The existence and the relative size of S1, S2 and S3 spots seemed to be species specific and the characteristics appeared at high reproducibility if King's B medium was used (Fig. 1). In the case of $P$. cepacia, spot $\mathrm{S} 1$ was larger than $\mathrm{S} 2$ and $\mathrm{S} 3$, and spot $\mathrm{S} 2$ was sometimes quite faint. While, $S 2$ spot was larger than $\mathrm{S} 1$ and $\mathrm{S} 3$ in case of $P$. caryophylli (Fig. 4). The chromatograms of $P$. glumae, $P$. gladioli and $P$. plantarii resembled each other. Especially, chromatograms of $P$. glumae and $P$. gladioli were not distinguishable, easily. However, a small difference between the chromatograms of these two species was sometimes observed for the ratio in size of spots S1 and S3 (Matsuyama and Furuya, 1993e). The size of spot S3 in P. plantarii is larger than S1 and S2 (Matsuyama et al., 1993d, Matsuyama and Furuya,1993e). This characteristic of P. plantarii was always observed on the chromatograms of three isolates used.

The chromatograms of $P$. andropogonis and $P$. solanacearum are roughly similar but different in detail(Fig. 2,3). The spot at Rf 0.83 which was detectable by the spraying of the chromium-containing $55 \%$ sulfuric acid and heating at $110^{\circ} \mathrm{C}$ existed on the chromatogram of $P$. undropogonis and not on that of $P$. solanacearum.

In the case of $P$. rubrisubalbicans, the profile was quite different from those of other 


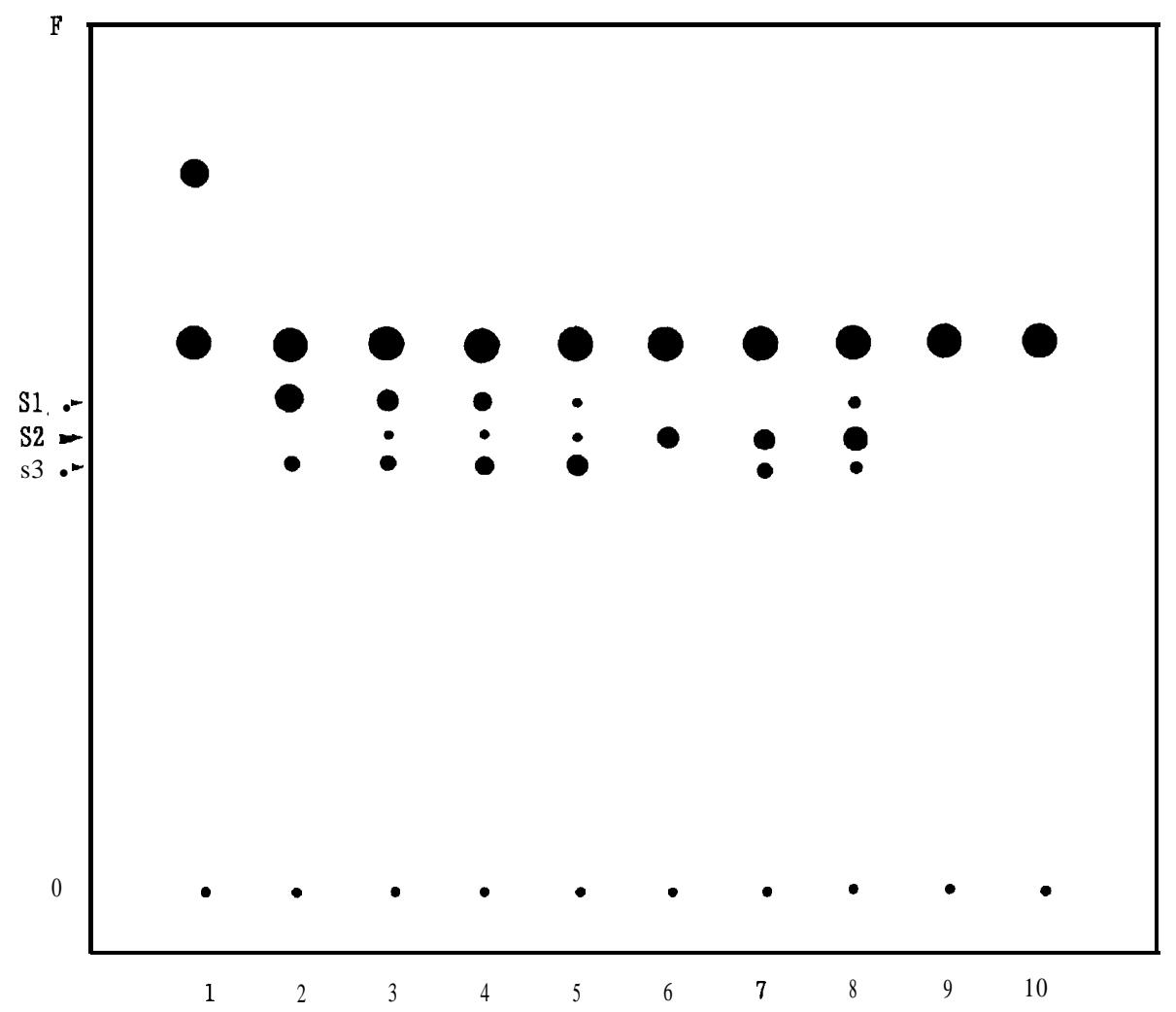

Fig. 1. Diagrammatic representation of TLC chromatogram of lipids from phytopathogenic bacteria.

1: Pseudomonas rubrisubalbicans, 2: $P$. cepacia, 3: $P$. gladioli, 4: $P$. glumae, 5: P. plantari, 6: P. solanacearum, 7: P. andropogonis, 8: P. caryophylli, 9: P. syringae, 10: $P$. avenae

F: Solvent front, O: Origin

Arrow heads indicate S 1, S2 and S3 spots, respectively.

members of the homology group II. As can be seen in Fig. 1, 2, the spot at Rf. 0.71 appeared and the benchmark spots S1,S2 and S3 were absent. This individuality of $P$. rubrisubalbicans has been reported at the fatty acid analysis (Young et al., 1992).

In this experiment, a practical usefulness of this direct colony TLC method for rapid identification of the phytopathogenic bacteria was repeatedly certified. Further, this novel technique gave lots of informations for the systematic bacteriology. Especially, the data on isolates of the homology group II in genus Pseudomonas will be meaningful for the discussion on the transferring of these pseudomonads as the members of Burkholderia gen. nov. 


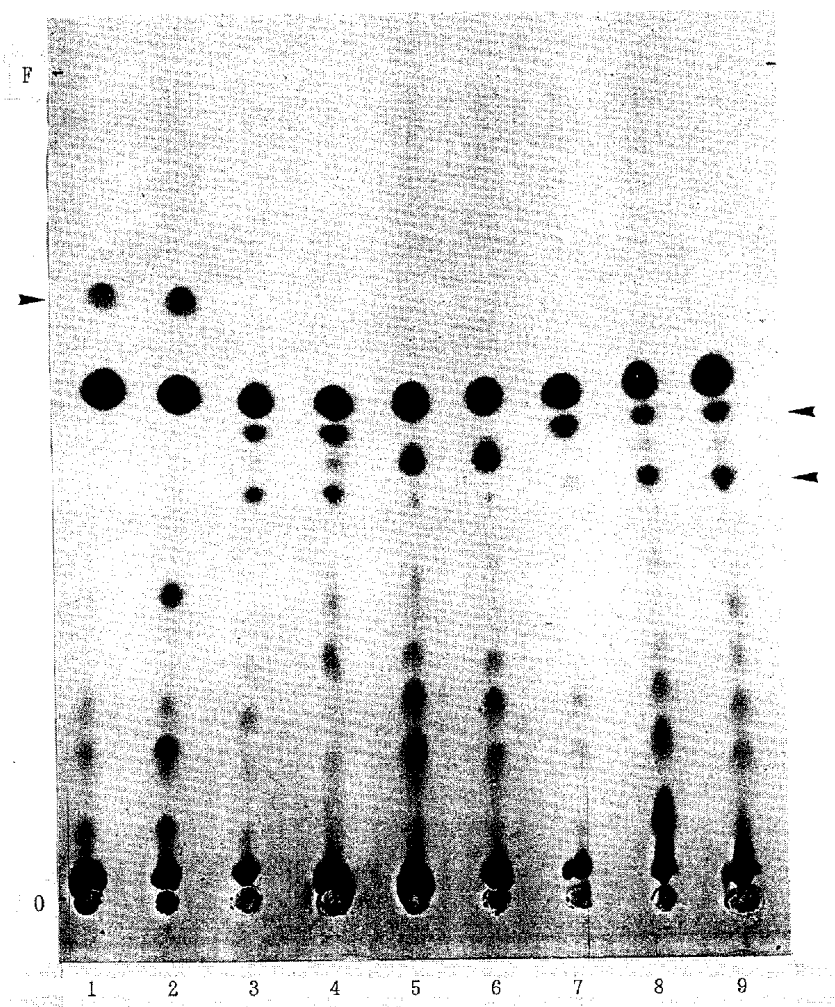

Fig. 2. TLC chromatogram of lipids from phytopathogenic bacteria

\begin{tabular}{|c|c|c|c|}
\hline & & us "tbalbicans & MAFF 301628 \\
\hline 2: & " & gladioli & MAFF 301626 \\
\hline 3: & " & gladioli & $251-17$ \\
\hline 4: & " & $"$ & 1065 \\
\hline 5: & " & andropogonis & MAFF 301006 \\
\hline 6: & " & " & MAFF 301129 \\
\hline 7: & " & cepacia & $356-3$ \\
\hline 8: & " & glumae & 2 \\
\hline 9: & " & " & N 7503 \\
\hline
\end{tabular}

F: Solvent front, 0: Origin

Arrow head of left-side represents benchmark of P. rubrisubalbicans and those of right-side represent benchmarks S1 and S3. 


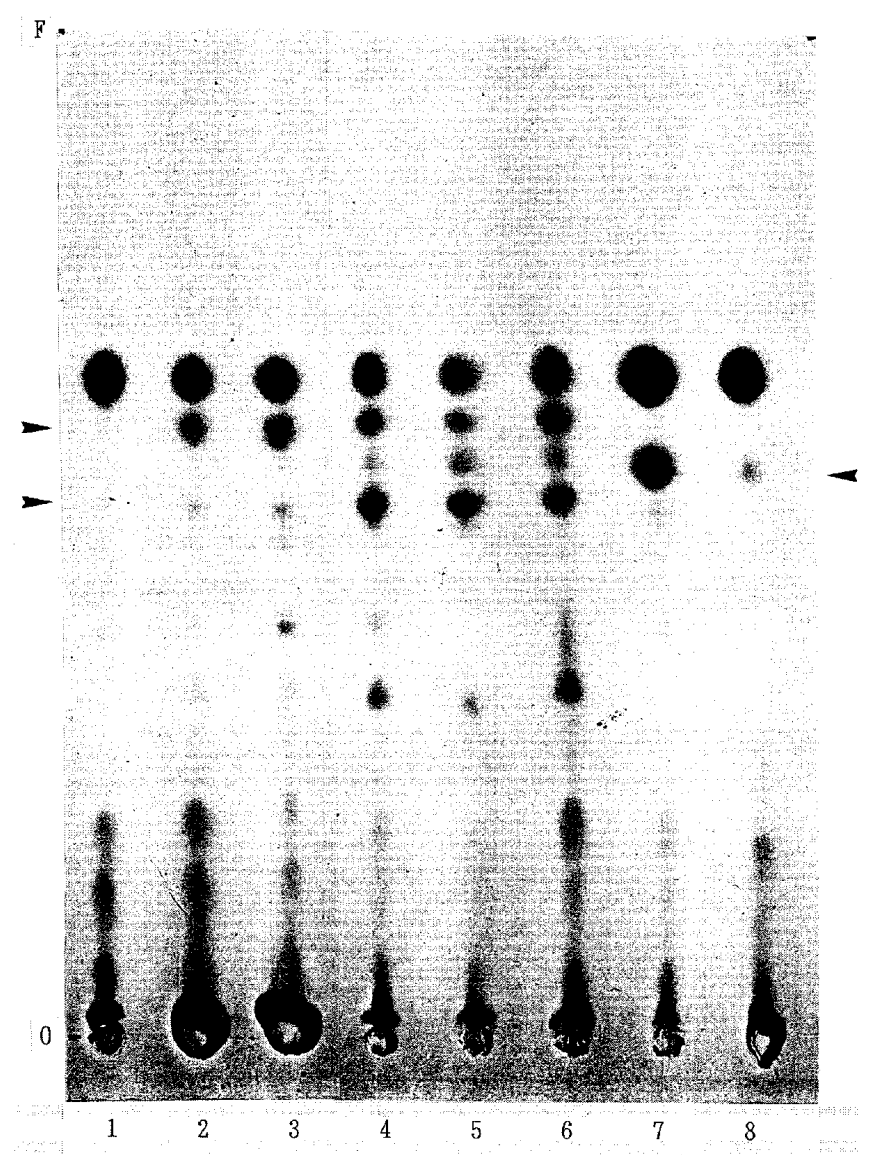

Fig. 3. TLC chromatogram of lipids from phytopathogenic bacteria. $\mathrm{I}$ : Comamonas acidovorans ATCC 15668

2: Pseudomonas cepacia $356-3$

3: " " ATCC 25416'

4: "gladioli goladioli 251-17

5:" " " "

6: " glumae 2

7: " solanacearum C319SR

8: " " 6211

F: Solvent front, 0: Origin

Arrow heads of left-side represent benchmarks S1 and S3 spots and that of right-side represents benchmark S2 spot.

4: Three days culture, 5: Twelve days culture. 


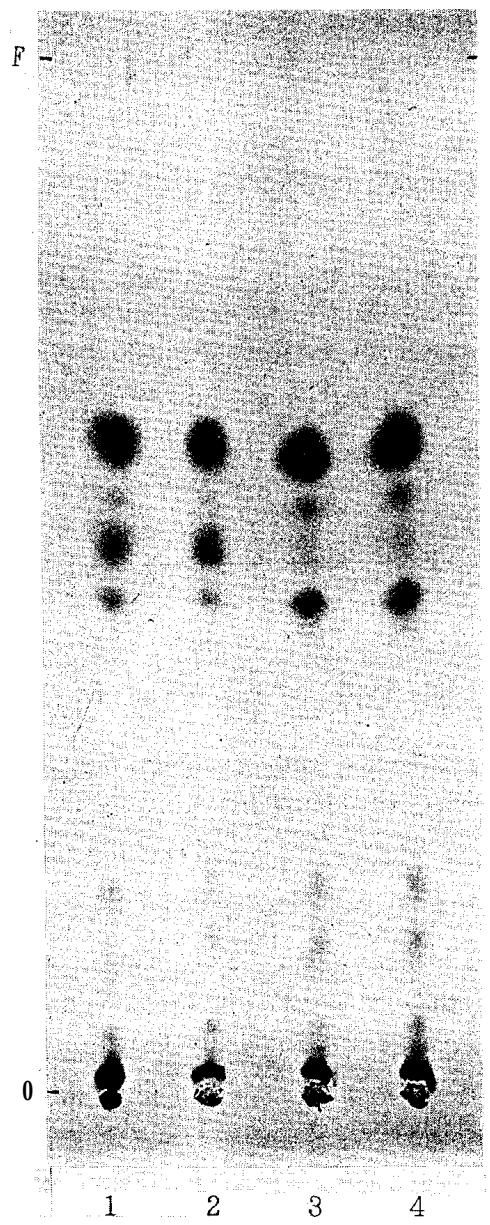

Fig. 4. TLC chromatogram of lipids from phytopathogenic bacteria.

$\begin{array}{lll}\text { 1: Pseudomonas caryophylli } & 1192 \\ \text { 2: " } & \text { " } & \mathbf{1 4 0 6} \\ \text { 3: } & \text { plantarii } & \mathrm{AZ} 8201^{\mathrm{T}} \\ \text { 4: } & \text { " } & \end{array}$

F: Solvent front, 0: Origin

\section{ACKNOWLEDGEMENT}

The author is indebted to the staff of the Institute of the Biological Resources, Tsukuba and Dr. N. Furuya of author's laboratory for their kind supply of the phytopathogenic bacteria. 


\section{REFERENCES}

De Vos, P. and J. De Ley 1983 Intra- and intergeneric similarities of Pseudomonas and Xanthomonas ribosomal ribonucleic acid cistrons. Int.J.Syst.Bacteriol., 33: 487-509

De Vos, P., M.Goor, M. Gillis and J.De Ley 1985 Ribosomal ribonucleic acid cistron similarities of phytopathogenic Pseudomonas species. Int. J.Syst.Bacteriol., 35: 169-184

Matsuyama, N. 1993a Rapid identification of phytopathogenic bacteria by the direct colony thin-layer chromatography. Proc. 6th International Congress of Plant Pathology, Montreal, Canada, p44

Matsuyama, N., Ismail Hossain Mian, Abdul Mannan Akanda and N. Furuya 1993b Application of the direct colony TLC method for identification of phytopathogenic bacteria. J.Fac. Agr. Kyushu Univ., 37(3,4): 281-285

Matsuyama, N., Ismail Hossain Mian, Abdul Mannan Akanda and N. Furuya 1993c Rapid identification of phytopathogenic bacteria by the direct colony thin-layer chromatography (1). Proc. Assoc., PL. Prot. Kyushu, 39: 60-64

Matsuyama, N., Ismail Hossain Mian, Abdul Mannan Akanda and N. Furuya 1993d Comparative studies on thinlayer chromatograms of lipids from various phytopathogenic bacteria. Ann. Phytopath Soc. Japan, 59: 528-534

Matsuyama, N. and N. Furuya 1993e Application of the direct colony TLC for identification of phytopathogenic bacteria (II) Chromatographic profile of Erwinia and Pseudomonus spp. J.Fac.Agr. Kyushu Univ, $\mathbf{3 8}(1,2): 89-95$

Matsuyama, N. 1995 Trial for rapid identification of phytopathogenic bacteria by HPLC and the direct colony TLC. J.Fuc. Agr. Kyushu Univ., 40: in press

Matsuyama, T., M. Sogawa, K. Kaneda and I. Yano 1986 Rapid detection and identification of bacterial lipids by direct colony thin-layer chromatography. Proc. of 23rd International Symposium of Advances in Chromatography, Chiba, Japan,pp127-128

Matsuyama, T., M. Sogawa and I. Yano 1987 Direct colony thin-layer chromatography and rapid characterization of Serratia marcescens mutants deffective in production of wetting agents. Appl. Environ. Microbiol, 53:1186-1188

Palleroni, N. J., R. Kunisawa, R. Contopoulou and M. Doudoroff 1973 Nucleic acid homologies in the genus Pseudomonas. Int.J. Syst. Bacteriol., 23: 333-339

Stead, D. E. 1992 Grouping of plant-pathogenic and some other Pseudomonus spp. by using cellular fatty acid profiles. Int. J. Syst. Bacteriol., 42: 281-296

Yabuuchi, E., Y. Kosako, H. Oyaizu, I. Yano, H. Hotta Y. Hashimoto, T. Ezaki and M. Arakawa 1992 Proposal of Burkholderia gen. nov. and transfer of seven species of the genus Pseudomonas homology group II to the new genus, with the type species Burkholdeliacepacia (Palleroni and Holmes 1981) comb. nov. Microbiol. Immunol., 36(12):1251-1275

Young, J. M., Y. Takikawa, L. Gardan and D. E. Stead 1992 Changing concepts in the taxonomy of plant pathogenic bacteria.Annu. Rev. Phytopathol, 30: 67-105 